\title{
PENGARUH SISTEM PENILAIAN KINERJA PEGAWAI DAN PENGEMBANGAN KARIR TERHADAP KEPUASAN KERJA PEGAWAI KANTOR PEMERINTAHAN KECAMATAN BARRU KABUPATEN BARRU
}

\author{
Kurnia $^{* 1}$, Muhammad Idris ${ }^{2}$, Asri $^{3}$ \\ Sekolah Tinggi Ilmu Manajemen Nobel \\ Program Pascasarjana Magister Manajemen, STIE Nobel Indonesia Makassar \\ Email: Kurniakadir73@gmail.com, muhamadiddris709@gmail.com, asri@stienobel-indonesia.ac.id
}

\begin{abstract}
ABSTRAK
Penelitian ini bertujuan untuk mengetahui dan menganalisis (1) pengaruh sistem penilaian kinerja pegawai dan pengembangan karir terhadap kepuasan kerja pegawai Kantor Pemerintahan Kecamatan Barru Kabupaten Barru secara sendiri-sendiri (parsial) dan secara bersama-sama (simultan) (2) variabel yang dominan berpengaruh terhadap kinerja pegawai Kantor Pemerintahan Kecamatan Barru Kabupaten Barru.

Penelitian ini menggunakan metode survei. Dilaksanakan pada Kantor Kecamatan Barru Kabupaten Barru. Waktu penelitian adalah bulan nopember sampai Desember 2019. Populasi dalam penelitian ini adalah seluruh pegawai Kantor Kecamatan Barru Kabupaten Barru, sebanyak 56 orang. Pengambilan sampel dalam penelitian ini menggunakan teknik sampling jenuh (sensus) yaitu semua populasi dalam penelitian ini dijadikan sampel. Sampel yang digunakan dalam penelitian ini adalah sebanyak 56 orang. Analisis data menggunakan analisis regresi berganda (multiple regression analysis).

Hasil penelitian menunjukkan bahwa (1) terdapat pengaruh positif dan signifikan antara sistem penilaian kinerja pegawai dan pengembangan karir terhadap kepuasan kerja secara parsial dan simultan terhadap kinerja pegawai pada Kantor Pemerintahan Kecamatan Barru Kabupaten Barru (2) pengembangan karir merupakan variable yang paling dominan berpengaruh terhadap kinerja pegawai pada Pemerintahan Kantor Kecamatan Barru Kabupaten Barru.
\end{abstract}

Kata kunci: sistem penilaian, pengembangan karir, dan kinerja

\begin{abstract}
ABSTRACK
This study aims to determine and analyze (1) the effect of the employee performance appraisal system and career development toward the employee job satisfaction at the Government Office in Barru Regency partially and simultaneously (2) the most dominant variable affects the employee performance at the Barru District Government Office in Barru Regency.

This study used a survey method and Implemented at the Government Office in Barru Regency from November to December 2019. The population in this study were all employees at the Government Office in Barru Regency by 56 people. Sampling in this study used a saturated sampling technique (census) in which all the population in this study were sampled. The sample used in this study were 56 people. Data analysis used multiple regression analysis.

The results show that (1) there is a positive and significant effect between the employee performance appraisal system and career development toward the job satisfaction partially and simultaneously on employee performance at the Government Office in Barru Regency (2) career development is the most dominant variable affects the employee performance at the Government Office in Barru Regency.
\end{abstract}

Keywords: appraisal system, career development, and performance 


\section{AkMen

PENDAHULUAN

\section{Latar Belakang}

Penerapan system penilaian dan pengembangan karir bagi instansi memperhatikan kepuasan pegawainya sehingga dapat menuju tercapainya tujuan organisasi. Kepuasan kerja pegawai akan sangat mempengaruhi sikap pegawai tersebut dalam melaksanakan tugas dan pekerjaannya. Sikap ini akan menentukan dedikasi, loyalitas dan prestasi terhadap pekerjaan yang dibebankan kepada pegawai. Faktor-faktor yang mempengaruhi kepuasan atau ketidakpuasan pegawai antara lain : jenis pekerjaan, rekan kerja, tunjangan, perilaku yang adil, keamanan kerja, peluang menyumbang gagasan, gaji/upah, pengakuan kinerja dan kesempatan bertumbuh. Ketidakpuasan pegawai dapat terjadi apabila pekerjaan yang dilakukan tidak sesuai dengan apa yang diperoleh dari organisasi. Ketidakpuasan pegawai dapat merugikan organisasi seperti meningkatnya kemangkiran pegawai, merosotnya kinerja pegawai, aksi mogok kerja dan tindakan negatif lainnya yang akhirnya akan berpengaruh pada tidak tercapainya tujuan yang telah ditetapkan organisasi.

Variable perubah dalam penelitian ini adalah system penilian dan pengembangan karir Dengan pengertian mengenai penilaian kinerja dan pengembangan karir dan hubungannya terhadap kepuasan kerja, maka perlu ditinjau hubungan diantara ketiga variabel tersebut. Hubungan yang pertama adalah hubungan antara penilaian kinerja yang memiliki keterkaitan yang erat dengan kepuasan kerja. Seperti yang dinyatakan oleh Luthan (2014:243) bahwa kepuasan kerja adalah keadaan emosi yang senang atau emosi positif yang berasal dari penilaian pekerjaan atau pengalaman kerja seseorang. Kepuasan kerja adalah hasil dari persepsi karyawan mengenai seberapa baik pekerjaan memberikan hal yang dinilai penting.

\section{Sistem Penilaian}

Mengacu dalam Penilaian kinerja pada sistem formal dan terstruktur yang digunakan untuk mengukur, menilai dan mempengaruhi sifat-sifat yang berkaitan dengan pekerjaan, perilaku dan hasil, termasuk tingkat ketidakhadiran. Dengan demikian penilaian kinerja adalah merupakan penilaian hasil kerja pegawai dalam lingkup tanggung jawabnya. Penilaian kinerja pegawai dapat diartikan sebagai sebuah mekanisme yang baik untuk mengendalikan pegawai. Penilaian kinerja pegawai yang dilakukan dengan benar, akan menguntungkan perusahaan karena adanya kepastian bahwa upaya-upaya individu memberikan kontribusi kepada fokus strategi perusahaan (Rivai, 2011:309-310).

\section{Pengembangan Karir}

Pada penelitian ini menjelaskan bahwa pengembangan karir adalah suatu penekanan pada pemberian bantuan dan kesempatan bagi para pegawai yang memungkinkan mereka untuk menyusun tujuan karir yang realistik, dan menyadari tujuan tersebut, bahwa perusahaan memiliki kewajiban untuk membantu para pegawainya menyadari kemampuannya, dan sebagian lagi karena pegawai percaya bahwa dengan mengintegrasikan "karier" individual dengan "karier" perusahaan, maka keduanya akan memperoleh keuntungan. Bagi pegawai, keuntungan yang jelas adalah kepuasan, pengembangan pribadi dan kehidupan kerja yang berkualitas. 


\section{Kepuasan Kerja}

Kepuasan kerja dan dilihat dari capaian kerja seperti yang dijelaskan oleh Rivai (2011) kepuasan kerja pada dasarnya merupakan sesuatu yang bersifat individual. Setiap individual memilki tingkat kepuasan yang berbeda-beda sesuai dengan sistem nilai yang berlaku pada dirinya. Makin tingggi penilaian terhadap kegiatan yang dirasakan sesuai dengan keinginan individu, maka makin tinggi pula kepuasannya terhadap keinginan tersebut

\section{METODE PENELITIAN}

Penelitian survey menurut Sugiyono (2012:7) yang dapat dilakukan pada populasi besar dankecil, tetapi data yang dianalisis berasal dari sampel yang diambil dari populasi tersebut sehingga ditemukan kejadian-kejadian relatif, distribusi dan hubungan antara variabel sosiologis maupun psikologis. Dengan demikian variabel- variabel yang diteliti tidak dikendalikan atau dimanipulasi oleh peneliti, tetapi fakta yang diungkapkan berdasarkan pengukuran gejala yang telah terjadi pada Kantor Kantor Kecamatan Barru Kabupaten Barru

\section{Hasil Penelitian}

\section{Uji Hipotesis}

\section{Uji t}

Uji t digunakan untuk mengetahui ada tidaknya pengaruh parsial (sendiri) yang di berikan oleh variabel independen $(\mathrm{X})$ terhadap variabel dependen $(\mathrm{Y})$. Ketentuan uji $\mathrm{t}$, jika nilai signifikansi kurang dari $0,05(\mathrm{sig}<0,05)$ maka variabel independen $(\mathrm{X})$ berpengaruh signifikan terhadap variabel dependen (Y). Jika thitung $>$ ttable maka Ho ditolak dan Ha diterima. seperti yang tertuang dalam tebel dibawah ini:

Tabel hasil pengujian hipotesis dengan uji $\mathrm{t}$ adalah sebagai berikut:

\begin{tabular}{|c|c|c|c|c|c|c|}
\hline \multirow{2}{*}{\multicolumn{2}{|c|}{ Model }} & \multicolumn{2}{|c|}{ Unstandardized Coefficients } & \multirow{2}{*}{\begin{tabular}{|l} 
Standardized \\
Coefficients
\end{tabular}} & \multirow[t]{2}{*}{$T$} & \multirow[t]{2}{*}{ Sig. } \\
\hline & & $\mathrm{B}$ & Std. Error & & & \\
\hline \multirow{3}{*}{1} & (Constant) & 3.690 & .899 & & 4.103 & .000 \\
\hline & X1 & .222 & .072 & .244 & 3.100 & .003 \\
\hline & $\mathrm{X} 2$ & .649 & .070 & .732 & 9.289 & .000 \\
\hline
\end{tabular}

a. Dependent Variable: Kepuasan kerja

Sumber: data diolah, 2020

\section{a. Pengaruh Sistem penilaian kinerja (X1) terhadap kepuasan kerja (Y)}

Berdasarkan hasil uji t untuk (X1) Sistem penilaian kinerja terhadap (Y) kepuasan kerja, menunjukkan nilai signifikan 0,003 dan thitung menunjukkan nilai 3,100. Artinya nilai signifikansi lebih kecil dari nilai probabilitas $0,05(0,000<0,05)$ dan thitung lebih besar dari ttable $(3100>2,000)$, dengan demikian Ho di tolak dan Ha diterima. Itu artinya Sistem penilaian kinerja secara parsial berpengaruh positif dan signifikan terhadap kepuasan kerja pada kantor kecamatan Barru kabupaten Baru. 
b. Variable (X2) Pengaruh Pengembangan Karir terhadap variable (Y) kepuasan kerja

Hasil uji t untuk Sistem penilaian kinerja (X1) terhadap kepuasan kerja (Y), menunjukkan nilai signifikan 0,00 dan thitung menunjukkan nilai 9.289. Artinya nilai signifikansi lebih kecil dari nilai probabilitas $0,05(0,00<0,05)$ dan thitung lebih besar dari ttable $(9.289>$ 2,000), dengan demikian Ho di tolak dan Ha diterima. Maka kesimpulannya, Pengembangan Karir secara parsial berpengaruh positif dan signifikan terhadap kepuasan kerja pada kantor kecamatan Barru kabupaten Baru.

\section{Uji F}

Uji F (uji simultan) bertujuan untuk mengetahui ada atau tidaknya pengaruh simultan (bersama-sama) yang diberikan variabel independen $(\mathrm{X})$ terhadap variabel dependen (Y). Uji F dilakukan dengan membantingkan antara Fhitung dengan Ftabel. Ketentuan uji t, jika nilai signifikansi kurang dari 0,05 (sig < 0,05) maka variabel independen $(\mathrm{X})$ berpengaruh signifikan terhadap variabel dependen $(\mathrm{Y})$.

Tabel hasil Uji Simultan (Uji F)

\begin{tabular}{|c|c|c|c|c|c|c|}
\hline \multicolumn{1}{|c|}{ Model } & Sum of Squares & Df & Mean Square & F & Sig. \\
\hline \multirow{4}{*}{1} & Regression & 157.368 & 2 & 78.684 & 192.939 & $.000^{\mathrm{b}}$ \\
& Residual & 21.614 & 53 & .408 & & \\
& Total & 178.982 & 55 & & & \\
\hline
\end{tabular}

a. Dependent Variable: Y

b. Predictors: (Constant), X2, X1

Sumber: data diolah, 2020

\section{Pengaruh Sistem penilaian kinerja, Pengembangan Karir terhadap kepuasan kerja pada Kantor Kecamatan Kabupaten Barru.}

Tabel diatas merupakan hasil pengujian dengan menggunakan SPSS 20, seperti yang tertera pada tabel bahwa tingkat signifikansi 0,000. Nilai signifikansi tersebut lebih kecil dari $0,05(0,000<0,05)$. Adapun nilai Fhitung yang tertera pada table di atas adalah 192.939 sedangkan nilai Ftabel yang di peroleh adalah 2,753, itu artinya Fhitung $>$ Ftabel $(192.939>2,753)$. Sehingga dapat disimpulkan bahwa Ho di tolak dan Ha diterima, dengan demikian dapat dikatakan bahwa variabel Sistem penilaian kinerja (X1), Pengembangan Karir (X2) mempunyai pengaruh yang signifikan terhadap kepuasan kerja (Y) pada Kantor Kecamatan Kabupaten Barru.

\section{Uji $\beta$}

Analisis $\mathrm{R}$ square $\left(\mathrm{R}^{2}\right)$ atau koefisien determinasi di gunakan untuk mengetahui berapa persen pengaruh yang diberikan variabel independen $(\mathrm{X})$ secara simultan terhadap Variabel dependen (Y).

Nilai $\mathrm{R}$ dan $\mathrm{R}^{2}$ dapat dilihat pada table berikut:

Tabel 5.15

Model Summary

\begin{tabular}{|l|l|l|l|l|l|}
\hline Model & R & R Square & & Change Statistics \\
\hline
\end{tabular}




\section{AkMen \\ Volume 17 Nomor 3 September 2020 \\ Hal. 420 - 426 \\ e-ISSN : 2621-4377 \& p-ISSN : 1829-8524 \\ Hbmepage: https//e-jumal.stienobel-indonesia.acid/index.php/akmen

\begin{tabular}{|r|r|r|r|r|r|r|r|}
\hline & & & \multicolumn{1}{c|}{$\begin{array}{c}\text { Adjusted R } \\
\text { Square }\end{array}$} & $\begin{array}{c}\text { Std. Error of the } \\
\text { Estimate }\end{array}$ & R Square Change & F Change & df1 \\
\hline 1 & $.938^{\mathrm{a}}$ & .879 & .875 & .639 & .879 & 192.939 & 2 \\
\hline
\end{tabular}

Berdasarkan pengujian hipotesis secara parsial dengan menggunakan uji t, diperoleh nilai t yang paling besar adalah pengembangan karir, sehingga pengembangan karir (X2) merupakan variabel yang paling dominan berpengaruh terhadap kepuasan kerja Kantor kecamatan Barru kabupaten Baru.

\section{Pembahasan}

\section{Pengaruh Sistem penilaian kinerja terhadap kepuasan kerja}

Melihat hasil uji t, diketahui bahwa nilai thitung sebesar 3.100, sedangkan nilai tabel sebesar 2,000 dengan signifikansi sebesar 0,003 <0,05 berarti Ho ditolak dan Ha diterima, artinya variabel Sistem penilaian kinerja secara parsial mempunyai pengaruh positif dan signifikan terhadap kepuasan kerja pada Kantor kecamatan Barru kabupaten Baru.

\section{Pengaruh Pengembangan Karir terhadap kepuasan kerja}

Berdasartkan tabel hasil uji t, nilai thitung sebesar 9.289, sedangkan nilai tabel sebesar 2,000 dengan signifikansi sebesar $0,00<0,05$ berarti Ho ditolak dan Ha diterima, artinya variabel Pengembangan Karir secara parsial mempunyai pengaruh positif dan signifikan terhadap kepuasan kerja .

\section{Pengaruh Sistem penilaian kinerja, Pengembangan Karir secara bersama-sama terhadap kepuasan kerja}

Berdasarkan hasil perhitungan analisis regresi linear berganda, menunjukkan bahwa $\mathrm{F}$ hitung lebih besar dari pada $\mathrm{F}$ tabel $(192.939>2,00)$, dengan probabilitas terjadinya kesalahan $\mathrm{F}$ hitung yaitu sebesar 0,000 atau lebih kecil dari taraf kesalahan yang ditetapkan $(\alpha=0,05)$. Sesuai dengan kriteria yang telah disebutkan terdahulu yaitu probabilitas $<0,05$, maka Ho ditolak dan Ha diterima, artinya Sistem penilaian kinerja, Pengembangan Karir, mempunyai pengaruh yang signifikan terhadap kepuasan kerja pada Kantor kecamatan Barru kabupaten Baru.

\section{Variabel yang Paling Dominan Berpengaruh}

Dari keterangan pengujian hipotesis secara parsial dengan menggunakan uji t, diperoleh nilai t yang paling besar adalah pengembangan karir, sehingga pengembangan karir (X2) merupakan variabel yang paling dominan berpengaruh terhadap kepuasan kerja Kantor kecamatan Barru kabupaten Baru.

\section{SIMPULAN}

\section{Simpulan}

Secara parsial menunjukkan bahwa Sistem penilaian kinerja, Pengembangan Karir, secara sendiri-sendiri (parsial) mempunyai pengaruh positif yang signifikan terhadap kepuasan kerja pada Kantor kecamatan Barru kabupaten Baru. Sistem penilaian 
kinerja, Pengembangan Karir, secara simultan mempunyai pengaruh yang positif signifikan terhadap kepuasan kerja pada Kantor kecamatan Barru kabupaten Baru. Dan Variabel pengembangan karir yang paling dominan berpengaruh terhadap kepuasan kerja Kantor kecamatan Barru kabupaten Baru.

\section{Saran}

Hendaknya pihak Pimpinan pada Kantor kecamatan Barru kabupaten Baru memberi perhatian terhadap upaya dalam memotivasi untuk mendorong pegawai untuk lebih meningkatkan kinerja terutama pada pegawai baru yang mempunyai masa kerja yang relatif singkat. Perbaikan Sistem penilaian kinerja, Pengembangan Karir pegawai dilakukan dengan memberikan pekerjaan dan bertanggung jawab lebih besar, baik berupa keterampilan, kreatifitas, inovasi, waktu kerja, komunikasi, kesempatan, keputusan pengawasan dan penguasaan kerja sehingga kinerja akan lebih meningkat di masa yang akan datang.

Variabel pengembangan karir mempunyai pengaruh yang paling dominan terhadap kepuasan kerja , yang mana dalam hal ini ketegasan dalam menetapkan setiap aturan organisasi dan konsekuensinya perlu ditingkatkan lagi sehingga ada dorongan dalam diri setiap pegawai untuk meningkatkan kedisiplinannya dengan mentaati setiap aturan yang berlaku di kantor kecamatan Barru kabupaten Baru.

\section{DAFTAR PUSTAKA}

Arikunto,Suharsimi.2007 ManatemenPenelitian.Jakarta:Rineka Cipta.

Kerja Karyawan pada PT.Pertamina (Persero)Region IMedan. ThesisMagister llmuManajemen.. Medan.

Ekayadi,Septyaningsih.2009. Pengaruh Motivasi dan Pengembangan Karir terhadap Kepuasan Kerja Karyawan pada PT.Rimba jati raya Citrakarya. laporan Penelitian. Fakultas Ekonorni Universitas Gunadarma, Jakarta.

Ghozali,lmam. 2009. Aplikasi Analisis Multivariate Dengan Program SPSS.Edisi Keempat. Semarang: BP-Universitas Diponegoro.

Handoko, T Hani. 200I.Manajemen Personalia dan Sumber Daya Manusia. Yogyakarta:BPFE.

Hasibuan,S.P.Malayu. 2005. Manajemen Sumber Daya Manusia.Edisi Ketujuh. Jakarta: Bumi Aksara.

Luthans,Fred.2009. Organizational Behaviour.10thed Edisi Bahasa Indonesia. Yogyakarta:ANDI.

Mangkunegara,A.A.Anwar Prabu. 2006.Evaluasi Kinerja SDM Bandung: Refika Aditarna.

Manullang,M.2001.Manajemen Personalia. Jakarta: Ghalia Indonesia. 
Mathis, Robert L dan Jhon H.Jackson. 2009. Human Resource Management. Edisi Bahasa Indonesia. Jakarta: Salemba Empat.

Moekijat, 2006. Dasar-Dasar Motivasi. Jakarta: PionirJaya.

Mondy, R.Wayne. 2008. Human Resource Management.l0 thed. Edisi Bahasa Indonesia Jilid 1.Terjemahan Bayu Airlangga,M.M.Jakarta:Erlangga.

Nawawi, H.Hadari. 2008.Manajemen Sumber Daya Manusia Untuk Bisnis Yang Kompettitif. Yogyakarta: GadjahMada University Press.

Noe, Raymond A.2007.Human Resource Management :Gaining acompetitive advantage.6thed USA:McGRaw-Hill.

Panggabean, Mutiara. S 2002 Manajemen Sumber Daya Manusia. Jakarta: Ghalia Indonesia.

Rivai, Veithzal. 2004. Manajemen Sumber Daya Manusia untuk Perusahaan. Jakarta: PT. Rajagrafindo Persada.

Rivai, Veithzal. 2006, Performance Apraisa/: Sistem yang Tepat Untuk Menilai Kinerja dan Meningkatkan Daya Saing Perusahaan. Jakarta:PT. Rajagrafindo Persada.

Robbins, Stephen. P. 2008. Perilaku Organisasi .Edisi Keduabelas. Jakarta: Salemba Empat.

Saksono, Slamet. 2003. Administrasi Kepegawaian.

Sastradipoera, Komaruddin. 2006. Pengemhangan dan Pelatihan: Suatu Pendekatan Manajemen Sumber Daya Manusia. Bandung: Kappa-Sigma.

Siagian, Sondang P. 2007. Manajemen Sumber Daya Manusia Jakarta:Bumi Aksara.

Simanjuntak, Payman. J. 2005. Manajemen dan Evaluasi Kinerja. Jakarta: LPFEUL

Simamora, Hendry. 2001. Manajemen Sumber Daya Manusia. Edisi Kedua. Yogyakarta: STIE YKPN.

Soeprihanto, John. 2001.Penilaian Kinerja dan Pengembangan Karyawan. Yogyakarta:BPFE.

Wibowo. 2007. Managing Change: Pengantar Manajemen Perubahan. Jakarta: PT. Raja Grafindo Persada. 